\title{
The Duchess of Malfi and El mayordomo de la duquesa de Amalfi Revisited: Some Differences in Literary Convention and Cultural Horizon
}

\author{
Luciano García García \\ Universidad de Jaen
}

\begin{abstract}
From the large bulk of national English and Spanish drama, those plays which happen to coincide in dealing with the same subject offer themselves as a privileged domain where a fruitful contrastive analysis can be carried out with a view to eliciting the divergent conventions and ideological values which rule in different and even opposing ways the production of literary works in seventeenth century England and Spain. To analyse and contrast some of those elements in The Duchess of Malfi and El mayordomo de la duquesa de Amalfi and put them in relation with their social, ideological and canonical context is the aim of this paper as a way of showing not only the literary practice in different societies, but how the notion of value in its Bakhtinian sense must be taken into account when assaying the appreciation of literary works stemming from divergent backgrounds.
\end{abstract}

After finishing his review of the studies on Anglo-Spanish relationships in seventeenth century drama, John Loftis, one of the most reliable modern scholars in this domain, states that the scarcity of proven instances of influences from the Spanish comedia upon English drama should stimulate the specialists to continue rather than to forsake the pursue of comparative studies, shifting from the search for sources to the most rewarding field of contrastive studies. He ends his article with these words: "Let us direct our attention to the resemblances and also the differences: for example, to the respective relationships of the plays to classical drama, classical literary criticism, and Renaissance commentary; to the conception of tragedy in the two countries; to the nature of Lope de Vega's and Shakespeare's history plays; to the conventions controlling Spanish and English dramatic 
dialogue..." ("English Renaissance" 248). Certainly, Loftis' words are in line with the renewal of the comparative studies prompted by the crisis of Comparative Literature itself and the advent of postmodernist criticism; and the enormous quantity of present contrastive studies devoted to the elucidation of differences as well as similarities between Spanish and English authors or plays bears witness to the topicality of this direction in comparative studies. The comparison between El mayordomo de la Duquesa de Amalfi by Lope de Vega and Webster's The Duchess of Malfi has so far received a certain amount of critical attention which points to its progressive consecration as one of the privileged grounds for discussion concerning English and Spanish dramas. ${ }^{1}$ Although a possible, if unlikely, relationship of influence between the two plays is not to be totally discarded, the play for the most part has proved to be a store of possibilities for contrast and coincidences. The reasons for this are easy to see: both plays are grounded in the same source $^{3}$ and deal with the same topic; both plays were written about the same time; ${ }^{4}$ both belong more or less to the same genre; ${ }^{5}$ and, finally, both are by canonical playwrights in their respective cultural and social milieus.

Loftis gives a series of reasons for considering both plays good. However, when undertaking an evaluative assessment, he virtually evades an axiological judgement by saying that they are not comparable. ${ }^{6}$ This is no surprise if we take into account the blurred area in which the social values (moral, religious, political, etc.) enter into the work of art and operate as aesthetic principles, roughly what Bakhtin termed "values". For the scholar who is able to view a play from the stance of the culture to which it belongs through years of a process of patient familiarization with background knowledge about that play it is difficult sometimes to express an uncompromising judgement; for, different from the general public, he is able to judge not only in modern terms, but also according to the values assigned to the work of art by the society of its time. So viewed, it is difficult to say that The Duchess of Malfi is a better play than El mayordomo, for, despite the degree of technical fulfilment of each play, dependent on particular conventions, our response is not to be entirely orientated by our horizon of expectations and our sympathetic or unsympathetic alignment with the peculiar view of the world proposed. ${ }^{7}$ If we indulge in judging from this latter stance, however, I prefer the Duchess of Malfi, of course, for it is a play that lends itself better to the current tastes and expectations of the late 20 th century reader, even if this reader happens to be Spanish.

Now my proposal here is to probe whether, from the comparison and analysis of three traits of the plays by Lope de Vega in contrast with the corresponding ones by Webster, some regular patterns of difference responding to the cultural and ideological background standing behind the literary practice of both dramatists might be revealed. I will attempt to look into some of the constraining limits in the cultural series defining the horizon of expectations of the audiences addressed by each author. It is my contention that, far from constituting a barren activity, the study and reconstruction of the historical contcxt in which the plays were first born and developed can enrich our awareness of the limits of literary appreciation as well as our insight into the plays.

The first obvious trait is one relating to genre, and concerns the alleged absence of tragical feeling in Spanish literature versus the clear-cut definition of that genre in England. It has been said that the Christian tradition embodied in the orthodox 
manifestation represented by the Tridentine Catholicism of Spain, thwarted the possibility of development of a strong tragical sensibility and, consequently, of a literary development of that kind. Despite the existence of some rather jaded and starched samples of classical pieces by Fray Jerónimo Bermúdez, Cristobal de Virués and others, the canonical forms of Spanish drama, are, for the most part, alien to tragedy. Comedies we have in the most classical sense; and we have the characteristically Spanish comedia which should be understood as tragicomedy; but what we lack, in general, is the tradition of appalling, disturbing and destabilising tragedies, whether political, historical or of revenge, so profuse in the Elizabethan tradition. The Middle Ages and the Spanish Renaissance and Baroque periods are alike in this respect, and the explanation is the same: an ideological horizon rigidly dominated by the idea of Christian redemption precludes the emotional experience of either earthly or cosmic tragedy. The world is presided over by an unquestionable rightful order which justly saves or condemns (or rather redeems or is prevented from doing so by the free rejection of the sinner), so that there is nothing to agonize about. The protagonist may suffer in this world, but in the long run he shall be saved as soon as he undergoes an orthodox death; the ghastly transcendental destiny of the damned, such as that of Paulus in El condenado por desconfiado is, after all, justly, if intricately, deserved and should serve as a due admonition to the faithful. As a consequence, the tragical feeling in Spanish dramatic literature is totally lacking or watered down up to the point of being considered, if cosmic, a just punishment, and, if earthly, a minor upheaval in the far more important run of spiritual salvation. ${ }^{8}$ Thus we get an important subject always entering into delineation of the tragical versus the tragicomical experience: the question of the happy ending. As the dramatic practice of the Christian Terence in Europe, or the first attempts at tragicomedy by Cinthio in Italy show, the sheer happy ending, the tragedy with a happy ending, or the tragedy with double issue (a happy ending for the good; an unhappy ending for the bad) are crucial issues that downgrade the intensity of tragedy making it tilt towards the neighbouring domain of tragicomedy. ${ }^{9}$

Then, if we talk about earthly catastrophes, it is no surprising that El mayordomo de la duquesa de Amalfi, which together with El castigo sin venganza is the closest approach of Lope to sheer tragedy, should be defective in tragical verve in comparison to The Duchess. To start with, although there is no denying that the Spanish play ends in a distressing (but not appalling) note of horror with the display of the beheaded corpses of her husband and children and the dying Duchess poisoned by the artful deceits of her brother Julio, the requisite horror of tragedy is, anyway, much less sustained throughout the whole play (which abounds, however, in lyrical notes) and a bit anticlimatic when arrived at in the end, if compared with the formidable mounting of tragical and cruel episodes in Webster's play and its uncompromising ending. I do not mean that Lope de Vega's play concludes in any kind of happy ending, but the tragical horror is considerably watered down both in the pursue of the tragical action throughout the play and, as I try to demonstrate here, in its deadly conclusion. It is as if Lope de Vega lacked the practice and the necessary world view to relentlessly pursue and conclude a concentrated tragical line, lapsing finally into an undecided tragical ending. The allowance made for Julio's reasons for the murder of the Duchess and her family, the inclusion of the young Duke of Malfi, the contrast of his benevolent acceptance of his mother's remarriage, and his somewhat 
ineffectual protest and menace against his murderous uncle result in a diversion of the tragical course towards a kind of ambiguous compliance with the issue of the vindication of familiar honour as represented by the attitude of Julio, and a defence of the nobility which, if ideologically points to the fact that true nobility as represented by the young Duke is naturally gracious, on the plane of tragical action serves only to create an anticlimatic situation, no matter how it could be defended as a calculated ambiguity on the part of Lope de Vega. ${ }^{10}$ There is in all the learned Spanish literature up to the Romantic period a coincidence with popular and medieval tastes (broadsides, popular songs, trashy verse) in never presenting a tragical event entirely deprived of either homiletic or pathetic connotations, with a strong accent on the sensational. And this is what I perceive in the ending of El mayordomo that places it far from the canonical tragedy. ${ }^{11}$ Webster, on the other hand, unrelentingly pursues his tragical line from the very beginning right up to the end and, although he locates the peak tragical moment in IV.ii with the death of the Duchess, the tragical denouement is successfully and coherently prolonged into the ensuing blood bath that reaches both further innocent people and the fosterers of evil, allowing a further extended span of horror and pity which makes a full tragical experience feasible. ${ }^{12}$

The second divergent trait that I would like to comment on stems from the aforesaid interpretation of genre and affects not the ending, but, as I have advanced above, plot structure. One of the most widely accepted features of Spanish comedia is the predominance of action versus insight, wit versus inquiry. This I relate to the absence of unorthodox questioning proper to theocratic autocracies (something of which seventeenth century Spain partook to a much higher degree than its contemporary England). As a result of the strict control of the religious and political establishment through the Inquisition and its Index of forbidden books and plays, and, no less importantly, as a result of the public opinion of the majority of the Spaniards, the least ideological dissent in matters of religion or politics was absolutely prevented. Indeed, conformity was more often exhibited, since a strong and militant profession of faith is condition sine qua non for a vast majority of Spanish plays, so much so that Jauralde Pou ("Introducción al estudio" 108) can rightly say in his general description of the Spanish comedia: "En este mundo de relaciones vivas y nítidas, sin embargo, pocas son las veces que los protagonistas actúan sólo y sobre todo por ellos mismos; al contrario, predominan los procesos de introspección y las evoluciones internas -monólogos - que provienen de un pesadísimo paraguas ideológico, de carácter sacro-feudal. El señalado aire de superficialidad y la calificación propagandística provienen, en la mayoría de los casos, de que todas aquellas relaciones que constituyen el cañamazo dramático tienen cierto aire de provisionalidad, son precarias y hasta ilusorias en tanto no llega algún tipo de sanción ideológica, cosa que el dramaturgo suele retrasar hasta los versos finales de la obra". This particular Spanish aspect, related to and, I suspect, as operating cause of the aborted development of a more classical bent (exemplified in the failure of the line of plays by Bermúdez, Virués or Lupercio de Argensola, for instance), precluded the intense tragical and questioning mood of Elizabethan tragedy and facilitated the triumphant Lopean formula of tragicomedy. What the constraining ideological framework of the Spanish society did and could not preclude, however, was a certain form of secularity which, although often frowned upon by the 
religious and political establishment, found a way out in fantasy, humour, witticism, scholastic quibbling, and novelesque episodes. Hence the two main forms of secular drama in Golden Age Spain are either sheer comedy or tragicomedy. ${ }^{13}$ Novelesque episodes under the form of peripety took up the dramatic space deserted when free speculation proved impossible and became one of the distinctive features of the Spanish plays, which, in this way, dismissed the concentrated intensity proper to sheer tragedy and developed traits of extension, breadth of treatment and inclusion proper to the epic, besides often resorting to a good deal of lyricism. It even contaminated the few attempts at tragedy made within the Lopean tradition, and precisely El mayordomo clearly illustrates, I think, the preponderance of varied and entertaining actions over an untiring and corroding quest for human motivations. The link, then, between this particular trait and the above question of the unsuitability of Spanish cultural milieu for tragedy is tragicomedy, a genre in which the proairetic and hermeneutic codes (in Barthes' words) ${ }^{14}$ are paramount. In this way, whereas in Webster's play the focus is taken up mainly by the presence of the characters, with long tirades in which the main ones (the Duchess, Bosola, Ferdinand, the Cardinal) discuss or uncover their motivations, and their actions are presented as the direct and even emblematic result of those motivations, in Lope the proairetic and hermeneutic material added to Bandello's original plot aims at creating new episodes of interest and suspense which, though perfectly integrated in the whole, somewhat detracts from the tragical unity and mood and suspends the tragical action, which is only set forth and solved well into Act III. ${ }^{15}$

Finally, I would like to refer to a last question having to do with the social conflict concerning class-boundary breaking and the destabilisation introduced by the misalliance of the Duchess in marrying a social inferior implicit in the two versions of the Amalfi topic. I maintain that this question bears heavily on the setting out of the action as either tragical or tragicomical, for, whereas a closer focus on this social conflict and its deadly consequences fosters the development of the action as tragical within the field of what I have termed earthly tragedy; a mitigation of it would mean, both in generic and in conventional terms, a distancing from that domain and onto the scope of tragicomedy. To be sure, the emotional stance of both Lope and Webster is clearly favourable to the Duchess, though the socio-textual explanation for this is different in each case. In the case of Lope de Vega, as it has been said, biographical factors and a widespread social view, often taking shape as a motif in Golden Age plays, makes it almost customary that the sympathies of the audience lie with the humble or poor knight (the hidalgo pobre), more as a mechanism of release of the social contradictions of the aristocratic order of seventeenth century Spain ${ }^{16}$ than as a social recognition of the new strength of the low gentry and the emerging bourgeoisie. The latter is precisely the meaning of the social conflict in Webster's play, although we must not forget that even seventeenth century England was by no means a democratic society, and that other factors, such as the objectionable transgressive impulse of the Duchess ${ }^{17}$ and the frequent disparagement of Mediterranean Catholicism (preferably that of Italy) are to be taken into account. In any case, the close and concentrated insight into this problem ${ }^{18}$ creates a real atmosphere of social transgression that acts perfectly as the social hubris of the play and which eventually affects everyone. ${ }^{19}$ So, against Jacks' (1975) criticism on Webster, arguing his defective 
moral view and lack of important dramatic purpose, one can allege that the critic simply overlooks something which is evident, i.e., that the play is fundamentally a tragical denunciation and an unspoken protest against the fixed social fate that prevent a basically honest and charming couple from fulfilling a private love which they have the right to enjoy. ${ }^{20}$ In this context Ferdinand and the Cardinal are the villains and blind instruments of fate that are finally caught up in the drift of the tragical action that they themselves have unleashed, Bosola exerting the ambiguous role of both a victim of the circumstances and a scourge of the innocent in a complex mixture of Jacobean malcontent and contemptu mundi satirist (note by D. C. Gunby in his edition of Webster, 1972: 437-8). So viewed, I do not doubt that Webster's tragical vision is powerful, which contrasts with the weakened view of Lope de Vega.

The Spanish author evades the full social implication of the conflict by watering down the aspect of the breach of class-boundaries through the development of parallel actions focused on the motif of love and jealousy (Urbino-Libia-Antonio, Otavio-Duquesaunknown suitor-Antonio, Bartola-Doristo in act II) which displace the interest from the social to the personal motives and add a certain romantic colouring to the plot, ${ }^{21}$ through the introduction of the young Duke of Amalfi and his acceptance of the remarriage of his mother (he even tells Antonio "que te estimo como a padre", III, p. 338), and through his sudden and quick resolution of the tragical action in one final stroke, which, despite its cruelty and horror, approaches the sensational rather than the tragic. ${ }^{22}$ To this it can be added that the villains are not two brothers and their creature Bosola (the Cardinal wisely kept in the background.), but just one brother (Julio) and an unrequited lover (Otavio), who only make their appearance as agents of mischief, if they can be truly termed so, in the middle of act III. Even then their villainous moral stance is qualified in the case of Otavio by his ignorance of the deadly plans of Julio and his final repulsion of them; and in the case of the latter possibly by the fact that his crime is related to the subject of honour (see note 10), something which to the Spanish eyes meets with indulgence even in preCalderonian times.

The three aspects examined revolve around the question of the impossibility of tragedy in Spain as a fundamental divide with the drama of England. It should be necessary to extend our examination to several other privileged pairs of plays for this sort of comparison. ${ }^{23}$ It would be in line with the proposal of Loftis above and would probably confirm what, I think, is a major trait and limit in the common ground of the two most important dramatic traditions in seventeenth century Europe. It would also meet the question of the values if we could only bridge the gaps between the social and the literary spheres through the cultural series. For lack of space I can only rough out the nonmechanical correspondence between two types of societies and their patterns of plays. On the one hand, we have in England a self-divided society in crisis, but highly dynamic and in social and economic progress; a pre-capitalistic society which finds in tragedy, recovered from the classics and remodelled, a literary form orientated towards the values of self-analysis, free inquiry and open interpretation out of a clear dogma which could alienate part of its audience. ${ }^{24}$ In opposition to this kind of social model, we find the static and close social order of Spain; a country where the signs of inner crisis are visible but ignored by a harmonious and unchallenged religious and political interpretation of the 
world shared by the majority of the population. To this type of society naturally corresponds a literary type which denies the radical questioning and destabilization of tragedy and opts for the more optimistic and escapist form of tragicomedy, with its focus on peripety and set characters. Although our contemporary world is much more like the one brought about by seventeenth century England rather than its contemporary Spain, seen from the point of view of the ideal of well-ordered (i.e, hierarchically and transcendentally organized) world, El mayordomo de la duquesa de Amalfi possesses its own beauty in its lyrical passages, its variety of action, its pathetic defeat of our hopes for a happy ending, and even its inconclusive suggestion of poetic justice through the ineffectual promises of revenge by the young Duke. In this sense, i.e., from the point of view of values, and leaving aside the comparison of technical questions like diction and type of verse, Loftis ("Lope de Vega's" 76) is right when he concludes his article enjoining that "we must not essay a comparison of incomparables".

\section{Notes}

1. As far as I know there are eight bibliographical items devoted wholly or partially to this topic. I quote them in chronological order: Kiesow, Gasparetti, Boklund, Brown, Loftis ("The Duchess of Malfi" and "Lope de Vega's"), Smith, and Brown.

2. See, for instance, Loftis ("The Duchess of Malf" 27 and "Lope de Vega's" 67, 71-72) for a summary and further reference to the episode of the exposed corpses of the Duchess' husband and children in Lope (end of Act III) and Webster (IV,i). In "The Duchess of Malf" (27-29) this same critic had tentatively proposed a rather implausible parallel image or example between $I, \mathrm{i}$, 488-491 of El mayordomo and I,i,488-491 of The Duchess.

3. The source for both plays is the 26th story in Bandello's Novelle, although other sources (Cinthio's Hecatommithi) are used for both plays; see Gasparetti (399-403) and Boklund (passim). For the general topic of the sources of The Duchess of Malfi see Kiesow, Lucas (23-25), Brown, (Introduction xxvii-xli), Loftis ("The Duchess of Malf" 27 and "Lope de Vega's" 67), Gunby (Critical Introduction 675-681).

4. Lope's Mayordomo is commonly dated between 1599 and 1606; Webster's Duchess, in 1614 or, more probably, the end of 1613.

5. There is always the vexing and far-reaching question of whether El mayordomo is a true tragedy. In any case, it clearly exemplifies the ultimate limits of the genre in Spain.

6. It must be said, however, that, of old, the work of Webster has been considered a better play than that of Lope de Vega. See, for example, the opinion of Adolf Friederich Schack (Historia de la literatura y del arte dramático en España, traducida directamente del alemán al castellano por Eduardo de Mier. Madrid: M. Tello. 6 tomos.1885-88:III, 95-96) as cited by Gasparetti (396), or Kiesow (257-258). Loftis himself ("The Duchess of Malf" 29-30), although already very cautious about stating an uncompromising judgement, admits that in treatment of motifs, recurrence of metaphors and images, and verse verve The Duchess is probably superior to El mayordomo. The only scholar who seems to declare himself in favour of El mayordomo is Adolf Schaeffer in his Spanische Literaturgeschichte (Leipzig, 1892, p. 101) as quoted by Kiesow (258).

7. See in this respect the article by Rodriguez Badendyck for a tenable though not necessarily assumable defence of the superiority of Castelvines y Monteses over Romeo and Juliet. 
8. In all this line of thought I align myself with Clifford Leech in Shakespeare's Tragedies, and Other Studies in Seventeenth Century Drama (London: Chatto and Windus, 1961), pp. 18 and 204, as quoted both by Muir $(214,216)$ and Loftis ("Lope de Vega's" 64-65). The question of whether a true genre of tragedy existed in the Golden Age drama is a major issue in the domain of Hispanic studies with a long list of critics in favour and against. All that I can say, in order not to unnecessarily enlarge the bibliography of this article, is that even the defenders of the genre posit a kind of tragedy "a la española" in the case of Lope de Vega and a type of Calderonian tragedy that demands the broadening of the current Aristotelian conception. The case of Rojas Zorrilla is different in that his tragedies fit better into the model. For a first approach to the topic through readily available items, see Jauralde Pou (115-116 and Bibliography) and Cruickshank $(32-35)$.

9. See for this issue Herrick, Chapters 2 and 3.

10. See the comments of Smith (84-85) on the possible contemporary interpretation of both The Duchess and El mayordomo. In his murder of the Duchess and Antonio, Julio could be interpreted as the guardian or regent of his green and inexperienced nephew in matter of honour as shown in his words of justification: "Sobrino, habláis como mozo/ yo he vuelto por vuestro honor, $/$ y esta venganza que tomo, $/$ a vuestra cuenta se ha hecho" (III, p. 340). It remains to be proved, however, whether the secret wedding of a widow may be a real case of honour. However, in allowing Julio to go unpunished, Lope, if in favour of the Duchess, is not complying with the maxim of poetic justice, something which seems to have been regretted by part of his audience and corrected by Diego Moxet de Solis' La venganza de la duquesa de Amalfi (published in Brussels in 1624).

11. Even the conception of tragedy continues to be the medieval view expressed by the Monk in The Canterbury Tales, i.e., the fall of a great man. Cf. the definition of a contemporary, Don Carlos Boil, for comedia (tragicomedy as we understand it) in "Cita a un licenciado que deseaba hacer comedia": "Después, licenciado mío,/ Que estas reglas y arte sepa,/ Un sugeto escogerá/ Que dé nombre á su comedia./ Supuesto el fin que el mayor/ De los que el aplauso aprueba,/ Es ver fingir un traidor/ Un leal, aunque le ofendan,/ Un perseguido de quien/La persecución desdeña,/ Un hombre á quien la fortuna/ O le sube ó le atropella,/ Un dadivoso Alejandro,/ Una Erífile avarienta,/ Un cruelísimo Neron (sic),/ Una piadosa Fedra;/ Porque destas circunstancias/El énfasis que se muestra,/ Suspende, y la suspensión/ De un cabello al vulgo cuelga". For tragedy, he seems to have a rather superficial conception: "La tragedia es todo Marte,/ Todo muertes, todo guerras" (in Ramón Mesonero Romanos B.A.E., 43: Dramáticos contemporáneos de Lope de Vega I pp. XXXVI). We must not forget, however, that this medieval reinterpretation of pity and horror was equally to be found in English literature in the popular domain and, partially, in the growing fashion for Fletcherian tragicomedy during the second half of the sixteenth century.

12. It is high time to confront here the tragicomical view of both the English tragedy and, particularly, The Duchess of Malfi, as it is more openly posited by Jacqueline Pearson (Chapters 1-4 and 6). While acknowledging that her general argument is acceptable in the sense that Elizabethan tragedy is not scrupulously the kind of tragedy represented by the classical Greek type, being, as it is, coloured by satirical and tragicomical elements, I think that she goes too far in overstressing the tragicomical character of Websterian plays (namely, The White Devil and The Duchess of Malfi) and leaves aside the fact that the bloody farcical and tragicomical elements, such as just retribution of evil (with Christian overtones) in the best tradition of the revenge play, do not preclude a strong tragical view whether sceptical and detached or highly moral, as it is proved by the number of critics opting for one interpretation or another, which, in any case, attest to the complexity of the play. Wymer favours a tragical view of The Duchess of Malfi $(52,60-61$ and 
67-71); and in comparing it with The White Devil expresses that "The character of the Duchess brings the play much closer to commonly perceived norms of tragedy, whether Shakesperean or Aristotelian. Terror is now conjoined with pity..." (52).

13. For a tentative classification of Spanish dramatic genres, with a view to a comparison with their counterparts in England, see my doctoral dissertation Presencia textual de España y de la literatura española en la obra dramática de James Shirley (1596-1666) (Universidad de Jaén, 1998), pp. 358-393. We must point out, anyway, that in England, approximately between 1610 and 1642, a kind of tragicomical drama usually termed Fletcherian tragicomedy, develops in connection with a genuine European tradition and similar in more than one respect to some of the current developments of Spanish tragicomedy developed by Lope de Vega.

14. In plain words: the aspects of the texts related to the development of action (proairectic) and to suspense or interest for what is going to happen next (hermeneutic).

15. The derivative episodes and complications of the main plot, some of them deeply rooted in the conventional motifs of Spanish drama, which delay and relegate the tragical denouement, are the parallel wedding of the rustics Doristo and Bartola (a motif found everywhere in Lopean comedy), the new-born baby inadvertently delivered to a stranger (see, for instance, Cervantes' $L a$ señora Cornelia or Tirso's Quien da luego, da dos veces), the complication introduced by the jealousy of Urbino over Libia and the courtship of the Duchess by Otavio, not to mention the hierarchically superior lady eliciting courtship from a social inferior (La ocasión perdida, $\mathrm{El}$ secretario de símismo, El perro del hortelano, Tirso's El castigo del penséque, etc.). The diverting passages in Webster (such as the reviling of the old lady by Bosola, the Julia development, the madmen's episode), however, never succeed in constituting discernible autonomous episodes, and are much more closely integrated into the dramatic action, both argumentally and thematically. It is worth mentioning as well that many motifs in The Duchess, such as the passage of the echo (V, iii), are deeply rooted, as is to be expected, in the English tradition (see Webster 434 in footnote by Gunby), Brown (xxxv), and Shirley's Love's Trick, IV,iii, 71, footnote in vol I of Dyce and Gifford's 1833 edition. See also Peele's Arraignment of Paris, III,ii). In fact, the echo motif can be traced back to Italian pastoral tragicomedy $I l$ pastor fido, IV,viii, which consecrated it as a convention in pastoral drama.

16. This issue is highly dependent on Lope de Vega's false democratism supported by Díez Borque (see his edition of Peribáñez y el Comendador de Ocaña, Madrid: Editora Nacional, $1975^{2}: 34$ y 36).

17. See for this aspect the article by Calderwood and Loftis ("Lope de Vega's" 74), who refers to Joyce E. Peterson (Curs'd Example: "The Duchess of Malfi" and Commonwealth Tragedy. Columbia: U. of Missouri P., 1978) for the culpability of the Duchess in her remarriage. This aspect is also treated, relating it to the social context of England, by John Russell Brown (xxxviiixxxix), and also by Gunby (Critical Introduction 386-387 and 394).

18. It is pertinent to bring up here that, whereas in El mayordomo the aristocratic if minor status of the secretary Antonio is clearly emphasized, in The Duchess it is not so, and even the Duchess reminds Bosola, as a feign objection against him, that "he was basely descended" (Webster III,ii, 258). Of course, I do not ignore that the social gap between a Duchess and a simple knight or gentleman (hidalgo or gentilhombre) is cause of scandal enough for the rigid class society of the early seventeenth century, though, theoretically, they both formed part of the nobility. See also the defence of merit versus lineage put up by the Duchess in III, 115-141.

19. To many critics one of the weak structural points of the Websterian tragedy is the death of the Duchess in the second scene of the fourth Act, which allegedly leaves the play without its nominal heroine one act ahead of the end. To me this is precisely a strong point, for Webster is 
able to extend the tragical denouement immediately to Cariola, then to Antonio and the children and, finally, to Ferdinand, the Cardinal and Bosola himself, so including every participant, innocent and guilty, in a kind of social purging of horror as a necessary sequel to the death of the Duchess of Malfi herself. This constitutes a significant contrast with the quick and limited use of terror by Lope de Vega in the last scene of the third act of El mayordomo and the inconclusive promise of revenge on the part of the young Duke of Malfi.

20 . The recognition by contemporary audiences of the personal right of the Duchess to live her own love in defiance of social pressures is difficult to elucidate for lack of specific references. Glimpses of general sympathy for the Duchess are more easily discernible, as in the case of Middleton's commendatory verses in the 1623 quarto edition of The Duchess of Malfi ("For who e'er saw this duchess live, and die,/ that could get off under a bleeding eye?'), and, with some qualifications in Rowley's ("Howe'er she answer'd her low-rated love,/ Her brothers' anger did so fatal prove"). From Pepy's Diary we only learn that it "seems a good play" and that it was "a sorry play". However, pieces of evidences such as the fact that Lewis Theobald's adaptation in 1733, provided the play with a happy ending, the Duchess being preserved by the providential precaution of a benevolent Bosola, and that an anonymous revision of 1707 bears the title of The Unfortunate Duchess, or The Unnatural Brothers suggest that the current appreciation was one of sympathy towards the Duchess and her actions and of censure for her brothers. See for this details Moore's John Webster and his Critics and Webster. The Critical Heritage. It is worth pointing out as well that, if in the remote source of the play (Bandello's twenty-sixth novella) there is no moral condemnation of the Duchess, the presumptive immediate sources of the English play (Painter's The Palace of Pleasure, following Belleforest) contains a great deal of disapprobation towards the actions and attitude of the Duchess, which means a conscious movement by Webster in presenting the titular protagonist in his own moral light. Modern critics, although acknowledging the faulty nature of the Duchess for seventeenth century standards, recognize her empathetic character. As Gunby (Critical Introduction 394) puts it "It is obvious, after all, where sympathy is meant to lie: whatever social conventions the Duchess has breached, nothing can justify what her brothers inflict on her". Wymer (59-60) very wisely (60) argues for the empathetic character of the Duchess even for the contemporary public.

21. It is high time to praise Lope de Vega's dexterity in the handling of different actions in one plot, seen, for instance, in the perfect integration of the motif of jealousy in three different developments of the same story, or in the way in which he offhandedly resorts to the death of Bartola in the third act as a subtle means to presage the death of the Duchess and an economical way to provide a convenient reunion of parents, children and faithful servants en route towards Amalfi and the final denouement of the play.

22. I think that tragedy requires a certain preparation and unity of action to be felt as such. It is significant that till the last moment Lope keeps open, and in fact seems to favour, the possibility of a happy ending, whereas Webster unfailingly pursues the tragical conclusion and reaches though does not exhaust it well before the end of the play with the assassination of the Duchess and Cariola. Lope, anyway, is only consistent with his Arte nuevo de hacer comedias, in which he advocates that "...la solución no la permita,/ hasta que llegue a la postrera escena;/ porque en sabiendo el vulgo el fin que tiene,/ vuelve el rostro a la puerta..." This, I think, is one of the sources of the haste or precipitation in which the comedia usually ends and might be advocated as one conventional reason for the impossibility of tragedy in El mayordomo and everywhere in Lopean plays.

23. I do not only think of such plays as Castelvines y Monteses and Romeo and Juliet, El mágico prodigioso and Doctor Faustus, El villano gran señor y gran Tamerlán de Persia and 
Tamburlaine, etc. in which a contrast between tragicomical and tragical moods can be effected, but also of plays such as El gran Duque de Moscovia and The Loyal Subject, in which the prevalent spirit is tragicomical.

24. It is pertinent to quote here what Muir (211) has to say about the English audience of the time: "The actors, moreover, performed before people of diverse religious views and they did not wish to cause offence. It must be remembered that many ordinary people born around 1530 would have been Catholics in 1545, that most of them would have been Protestants in 1550, Catholics in 1555 , and Protestants again in 1560 . Whatever their private views happened to be, they mostly conformed". The liking for tragedy was going, however, to recede a bit with the accession of the Stuarts and a vogue for tragicomedy which happens to coincide with the signing of peace with Spain in 1604 and then with a period of intensification of the literary influence of this country upon England (which, anyway, was never first rate).

\section{Works Cited}

Boklund, Gunnar. The Duchess of Malfi: Sources, Themes, Characters. Cambridge, Mass.: Harvard UP, 1962.

Brown, John Russell. Introduction. The Duchess of Malf. By John Webster. London: Methuen, 1964.

Brown, Laura Marie. Adapting the widow: "The Duchess of Malf" in Webster and Lope. Ph. D. Columbia University, 1996.

Calderwood, James L. "The Duchess of Malfi: Styles of Ceremony". In R. V. Holdsworth (ed.) Webster: The White Devil and The Duchess of Malfi. A Selection of Critical Essays. London and Basingstoke: Macmillan, 1975. 103-117. (Originally published in 1966 in Essays in Criticism XII).

Cruickshank, Don W. Introduction. El médico de su honra. By Pedro Calderón de la Barca. Madrid: Castalia, 1981.

Dent, Robert William. John Webster's Borrowing. Berkeley and Los Angeles: U. of California P, 1960.

Gasparetti, Antonio. "Giovan Battista Giraldi e Lope de Vega".Bulletin Hispanique 32: 372-403, 1930.

Gunby, David. "Introduction" to his edition of Three Plays (The White Devil, The Duchess of Malfi and The Devil's Law-Case). Harmondsworth: Penguin, 1972.

. Critical Introduction. The Works of John Webster. An Old-Spelling Critical Edition. Cambridge: Cambridge UP, 1995.

Herrick, M. T. Tragicomedy. Its Origins and development in Italy, France and England. Urbana: U. of Illinois P, 1955.

Jacks, Ian. "The Case of John Webster". In R.V. Holdsworth (ed.) Webster: The White Devil and The Duchess of Malfi. A Selection of Critical Essays, 1975, 76-83. (Originally published in 1949 in Scrutiny 16: 38-43).

Jauralde Pou, Pablo. "Introducción al estudio del teatro clásico español. Bibliografía". Edad de Oro 5 (1986): 107-147.

Kiesow, Karl. "Die verschiedenen Bearbeitungen der Novelle von der Herzogin von Amalfi des Bandello in den Literaturen des XVI und XVII Jahrhunderts". Anglia, Zeitschrift fïr englische Philologie 17 (1895): 199-258. 
Loftis, John. "The Duchess of Malfi on the Spanish and English Stages". Research Opportunities in Renaissance Drama 12 (1969): 25-31. ."Lope de Vega's and Webster's Amalfi Plays". Comparative Drama 16.1 (1982): 6478. “English Renaissance from the Spanish 'Comedia"'. English Literary Renaissance 14.2 (1984, Spring): 230-248.

Lucas, Frank Laurence. Introduction. The Duchess of Malf. By John Webster. London: Chatto \& Windus, 1958.

Moore, Don D. John Webster and His Critics, 1617-1694. Baton Rouge: Louisiana State UP, 1966.

(ed.). Webster. The Critical Heritage. London, Boston and Henley: Routledge and Kegan Paul, 1981.

Muir, Kenneth. "The Advantages and Disadvantages of Secularity". Parallel Lives: Spanish and English National Drama 1580-1680. Eds. Louise Fothergill-Payne \& Peter Fothergill-Payne. Lewisburg, PA, and London: Bucknell UP; Associated Ups, 1991. 211-23.

Pearson, Jacqueline. Tragedy and Tragicomedy in the Plays of John Webster. Manchester: Manchester UP, 1980.

Rodriguez Badendyck, Cynthia. "The Neglected Alternative: Shakespeare's Romeo and Juliet and Lope de Vega's Castelvines y Monteses". Parallel Lives: Spanish and English National Drama 1580-1680. Eds. Louise Fothergill-Payne \& Peter Fothergill-Payne. Lewisburg, PA, and London: Bucknell UP; Associated UPs. 1991. 91-107.

Smith, Dawn L. "Text, Stage, and Public in Webster's The Duchess of Malfi and Lope's El mayordomo de la duquesa de Amalfi". Parallel Lives: Spanish and English National Drama 1580-1680. Eds. Louise Fothergill-Payne \& Peter Fothergill-Payne. Lewisburg, PA, and London: Bucknell UP; Associated UPs. 1991. 75-90.

Vega Carpio, Félix Lope de. El mayordomo de la duquesa de Amalfi. En B.A.E., tomo 249 (Obras de Lope de Vega, tomo XXXI) 281-340. Madrid: Atlas, 1972.

Webster, John. Three Plays (The White Devil, The Duchess of Malfi and The Devil's Law-Case). D. C. Gunby (ed.). Harmondsworth: Penguin, 1972.

Wymer, Rowland. Webster and Ford. Basingstoke: Macmillan, 1995. (English Dramatists Series). 